careful consideration of any work that Professor Coleman had published on it. I am not aware that his second report was available when I prepared my address. Its issue was reported in Economic Geology for June, 1906; but as the paper is not included in the Annual List of Literature receired by the Geological Society for either 1905 or 1906 , I presume Economic Geology was supplied with an adranced copy. This view is supported by the fact that Professor Coleman, in a paper in the Journal of Geology for last month, published six months after the manuscript of $\mathrm{my}$ address had to be in the hands of the printer, refers to his report as " recently distributed." I notice, moreover, that there is no reference to it in Messrs. Campbell \& Knight's paper on the Microstructure of the Nickeliferons Prrrhotites, which was received in this country after my address had been delivered. As the report was apparently inaccessible to American authors, it is not surprising that it was not available on this side of the Atlantic. ${ }^{1}$

My opinion as to the origin of the Sudbury ores is not so emphatic as Professor Coleman's article would suggest. The opinion which he quotes was introduced by the words "appear to have been," and the next sentence continues the same expression of doubt-"if Dickson's facts be right," ete. Without having been in the field, I should be sorry to express a final opinion on either side. But so far as I am capable of judging from the literature, the igneous origin of the ores is not yet established, and is faced by greater difficulties than the alternative theory. Messis. Campbell \& Knight, in their recent paper in Economic Geology (June, 1907), also conclude that "Dickson has a weight of evidence to prove that his specimens are of secondary aqueous origin" (p. 351). They claim that (p. 365) in all the chief mining fields of nickeliferous pyrrhotite the mode of origin of the ores was the same, and that the basic rocks with which the ore bodies are associated were first formed, then fractured, and then "ore-bearing solutions came in and replaced the rock-matter wholly or in part by pyrrhotite. Later on the pyrrhotite, etc., was also strained and broken, and the deposition of pentlandite and chalcopyrite followed." Hence I am not the only one who is not yet convinced that the igneous origin of these ores is "the correct view."

J. W. Gregory.

Geological Departinent,

University, Glasgow.

January 31st, 1908.

\title{
KITCHES-MIDDENS IN NORTH CORNWALL.
}

SIR,-In Mr. B. B. Woodward's interesting paper in the Geological Magazine (January and February, 1908) on "The Drift and Underlying Deposits at Newquay," he mentions kitchen-middens and cooking-sites as occurring towards the upper parts of the deposit of sand (Fig. 1, p. 15, January). It may be interesting to note the similar occurrence in the Trevose district further to the north-east of many such kitchen-middens and cooking-sites. In October, 1901

1 I am informed (Feb. 17th) that Professor Coleman's report has not even yet been received at the Geological Society's Library. 
(in company with Mr. G. Bonsor, Dr. Thelwell, and Mr. Mallett) we found in the blown sand above the cliff near Constantine Island many traces of hearths, at different levels, down to a depth of 8 feet from the highest point of the midden. There were charcoal, burnt bones, and shells of Patella vulgata, Cordium edule, and Mytilus edulis (some showing traces of the action of fire on them). The fact of the differing levels of these hearths seems to show a prolonged occupation of the Trevose peninsula by Neolithic man or his descendants in the Bronze or early Iron ages. There is an extensive circular midden round Constantine Church (ruins), there are others covered with blown sand that can be identified by the shells and bones turned out by rabbits in making their burrows. Also an extensive midden occurred at the Harlyn Bay late Keltic burialground. I say occurred, because it has been levelled and planted with trees. From that kitchen-midden were obtained teeth of Bos taurus, Sus scrofa, and shells of Mytilus, Patella, Helcion, etc., and quantities of broken Purpura lapillus, which $\mathrm{Ir}$. Santer Kennard, F.G.S., considered were thus broken to extract colour for dyeing. I cannot verify the reference, as I do not keep the Illustrated London News, but, as far as I remember, Mr. George Bonsor, whose discoveries near Carmona have given him a European reputation, found somewhat similar conditions as to kitchen-middens and cooking-sites near St. Mary's in the Scilly Isles, but, so far as I know, his paper on this work has not set appeared.

i. Ashivgton Bullen.

Wokisg.

Febriary 5 th, 1908.

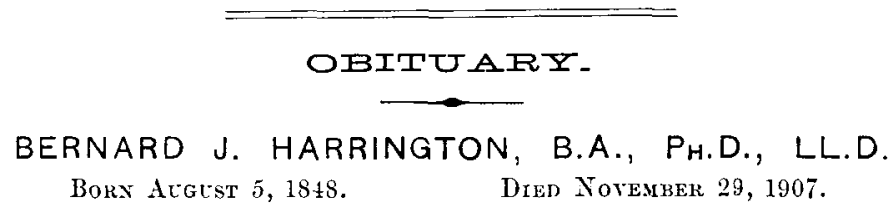

We regret to record the death of Dr. B. J. Harrington, who was formerly chemist and mineralogist to the Geological Survey of Canada, and subsequently Professor of Mining and also of Chemistry in McGill University, Montreal. Born in the province of Quebec he was educated at McGill University, and afterwards graduated Ph.D. at Yale. In 1872 he succeeded Dr. T. Sterry Hunt as chemist and mineralogist to the Canadian Geological Survey under Selwyn. To the publications of that Survey he contributed reports and analyses of coals, iron-ores, and sundry minerals. He also prepared a catalogue of the Canadian minerals, rocks, and fossils exhibited in the Paris Exhibition of 1878 . He described the new mineral Dawsonite (1874), wrote on the microscopic structure of dykes cutting the Laurentian rocks (1877), and on the minerals of some of the apatite-bearing veins of Ottawa County (1879). In later years he contributed papers on mineralogical subjects to the Transactions of the Royal Society of Canada, the American Journal of Science, and other journals. He had been President of the Chemical and Physical Section of the Royal Society of Canada, and he was appointed a Vice-President of 